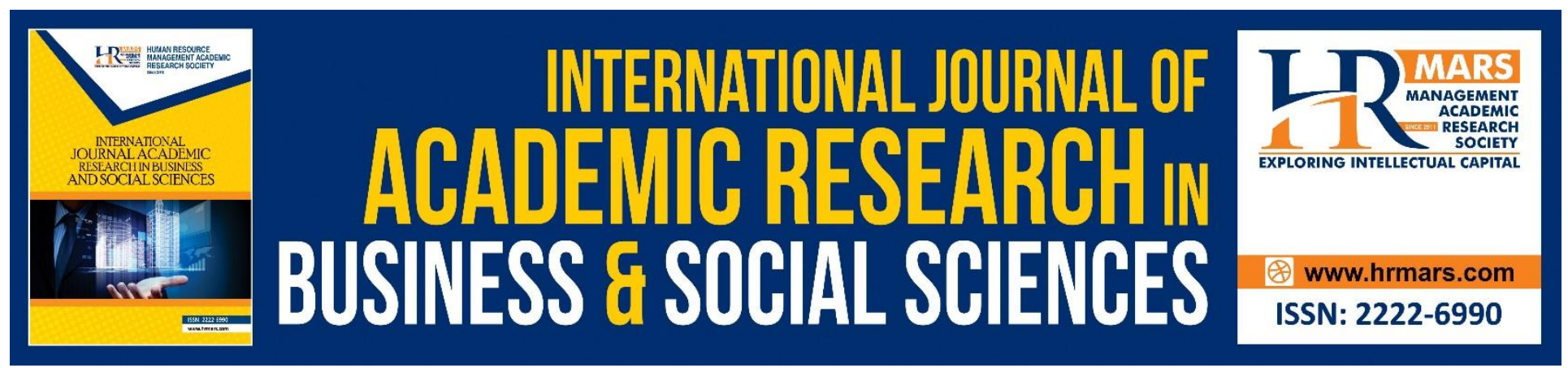

\title{
Service Quality, Food Quality, Image and Customer loyalty: An Empirical Study at a Hotel Restaurant
}

\author{
Mohd Aliff Abdul Majid, Azlina Samsudin, Mohd Hazrin Iman Noorkhizan, \\ Mohd Izwan Mohd Zaki \& Arma Mohd Faizal Abu Bakar
}

To Link this Article: http://dx.doi.org/10.6007/IJARBSS/v8-i10/5310 DOI: $10.6007 /$ IJARBSS/v8-i10/5310

Received: 15 Sept 2018, Revised: 13 Oct 2018, Accepted: 16 Oct 2018

Published Online: 28 Oct 2018

In-Text Citation: (Majid, Samsudin, Noorkhizan, Zaki, \& Bakar, 2018)

To Cite this Article: Majid, M. A. A., Samsudin, A., Noorkhizan, M. H. I., Zaki, M. I. M., \& Bakar, A. M. F. A. (2018). Service Quality, Food Quality, Image and Customer loyalty: An Empirical Study at a Hotel Restaurant. International Journal of Academic Research in Business and Social Sciences, 8(10), 1432-1446.

\section{Copyright: (C) 2018 The Author(s)}

Published by Human Resource Management Academic Research Society (www.hrmars.com)

This article is published under the Creative Commons Attribution (CC BY 4.0) license. Anyone may reproduce, distribute, translate and create derivative works of this article (for both commercial and non-commercial purposes), subject to full attribution to the original publication and authors. The full terms of this license may be seen

at: http://creativecommons.org/licences/by/4.0/legalcode

\section{Vol. 8, No. 10, 2018, Pg. 1432 - 1446}

Full Terms \& Conditions of access and use can be found at http://hrmars.com/index.php/pages/detail/publication-ethics 


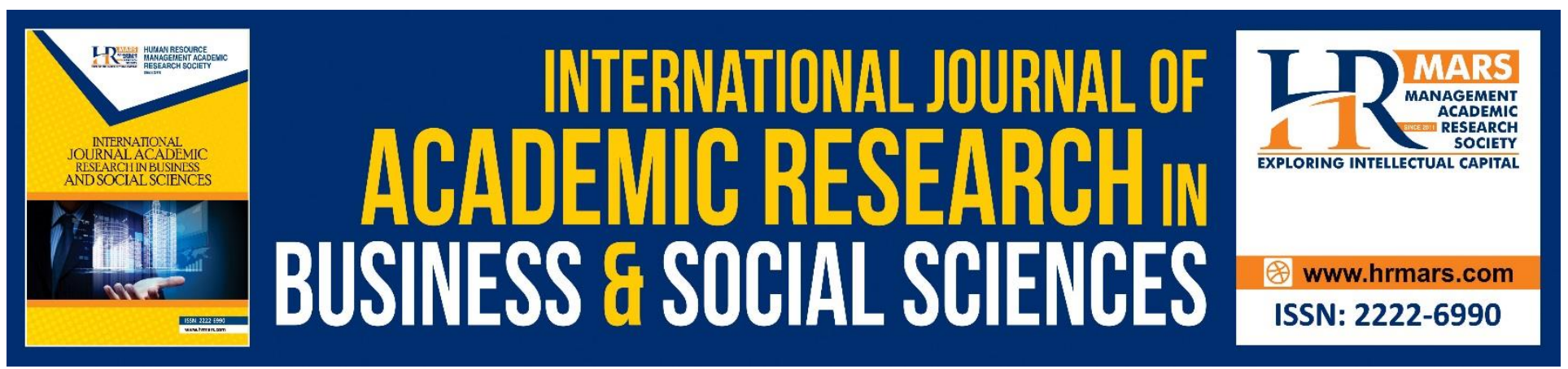

\title{
Service Quality, Food Quality, Image and Customer loyalty: An Empirical Study at a Hotel Restaurant
}

\author{
Mohd Aliff Abdul Majid ${ }^{1 *}$, Azlina Samsudin², Mohd Hazrin Iman \\ Noorkhizan ${ }^{3}$, Mohd Izwan Mohd Zaki \& Arma Mohd Faizal Abu \\ Bakar $^{5}$
}

${ }^{1}$ Faculty of Food Science and Technology, Universiti Putra Malaysia, 43400 UPM Serdang, Selangor, Malaysia

2,3,4,5 Faculty of Hotel and Tourism Management, Universiti Teknologi MARA Dungun, 23000

Terengganu, Malaysia

\begin{abstract}
This study investigates the relationship of service quality, food quality and image on customer loyalty at a hotel restaurant in Terengganu, Malaysia. A cross-sectional, quantitative approach consists of questionnaire was employed. Measures of service quality, food quality, image and customer loyalty were administered using convenience sample. A total of 231 usable data was analyzed using multiple regression. Food quality, service quality and image had significant contribution on customer loyalty $(p<.001)$. It revealed that service quality made the largest unique contribution $(\beta=.426)$, followed by image $(\beta=.251)$ and food quality $(\beta=.234)$. Improving food quality, service quality and image are not only enhancing customer loyalty, but helps to improve the restaurant's reputation and enhance sustainability.
\end{abstract}

Keywords: Customer Loyalty, Service Quality, Food Quality, Image, Hotel Restaurant

\section{INTRODUCTION}

\section{Background of the Study}

Changes in lifestyle have influenced the increasing number of dining out activities. Shamsudin and Selamat (2005) claimed that the rising of income and educational level, apparently, have impact on the lifestyle. Restaurants are one of the places to dine out in order to accommodate people's social and business activities (Wijaya, Widjaya \& Hariyanto, 2016). In Malaysia, the culture of dining out has boosted the development of restaurant industry (Salleh, Hashima \& Murphy, 2015). Evidence showed that, in general, the food and beverage establishments in Malaysia have witnessed an annual growth rate of 5.1\% since 2010, amounting to 167,490 establishments (Department of Statistics Malaysia, 2016). Seemingly, there is growing number of Malaysia's restaurants as the demand increases 
(Moorthy, Chee, Yi, Ying, Woen, \& Wei, 2017). Looking at the growing patterns, fierce competition waits. Hence, ensuring its survival in the competitive market becomes crucial.

Shoemaker and Lewis (1999) suggest that keeping existing customers is one of the strategies in marketing. Restaurant operators should give serious attention to switch their marketing strategy from attracting new customers to keep existing customers. Since the restaurants offer almost similar product and services, retaining loyal customers is the key survival in the competitive market. Ma, Qu and Eliwa (2014) identified three main reasons a restaurant might increase sales through loyal customer. First, loyal customers tend to be less price-sensitive, thus, slight change in pricing might not affect this group of customers. This is especially important for hotel restaurant where the restaurant is targeting group from business and corporate. Second, loyal customers visit more frequently and open for new menu and service offerings. Third, they are likely to spread positive word-of-mouth marketing, in which in return bringing new customers to the restaurant. Additionally, the effort of retaining loyal customers offer cost advantage as compared to attracting new customers (Wills, 2009).

Customer's demands had influenced the restaurant industry to fierce competitions (Majid, Alias, Samsudin \& Chik, 2016). As a result of competitive market, it is important to understand the factors in keeping the customers loyal (Soriano, 2002) and provide economic advantage (Polyorat \& Sophonsiri, 2010). By understanding the factors that associate with customers loyalty, customer's expectation might be satisfied, in return, generate plentiful revenue for the restaurant (Haghighi, Dorosti, Rahnama \& Hoseinpour, 2012). Lewis (1981) found that food quality, menu variety, atmosphere, convenience and price are important factors associated with dining experience. Seemingly, the significance of these factors varied according to the type of restaurants. Among various factors, indeed, delivering good service is required in the business operation and regarded as an important factor in keeping the loyal customers. Quality of food is also one of the determinants that influence the customer loyalty especially in restaurant context. Adding to that, restaurant image is seen as an important attribute for hotel restaurants (Ismail, Zahari, Shariff \& Suhaimi, 2016). Moreover, the restaurant carries the image of the hotel as it involved with the hotel operation. Therefore, service quality, food quality and image are employed in this study as the factors affecting customer loyalty in hotel restaurant.

Although the importance of hotel restaurant has evidently growing, it has not given much attention in research. Prior research in of customer loyalty derived from different restaurant settings including fine dining (Ma et al., 2014), café (Moorthy et al., 2017), quick-casual (Ryu, Han, \& Kim, 2008), chain restaurant (Polyorat \& Sophonsiri, 2010) and authentic restaurant (Ryu, Lee \& Kim, 2012). Previous studies on the relationship between food quality, service quality and image, and customer loyalty focused more on the restaurant industry with limited literature in the context of hotel restaurant. Thus, the main objective of this study is to determine the factors that influence customer loyalty in the context of hotel restaurant. Practically, this research can offer various insights in to the important role of hotel restaurant service quality, food quality and image on customer loyalty. 


\section{Statement of Problem}

Customer loyalty is crucial for the success for many restaurants (Eakuru \& Mat, 2008). As there are many hotel restaurants that provide similar products and services, loyal customers is the key to remain successful to reduce the likelihood of customers searching for substitute in the competitive market. Moorthy et al. (2017) define customer loyalty as customers who willingly to purchase repeatedly and offer word-of-mouth marketing for the particular business. Research found that it is a cost effective and valuable return for an organization as the loyal customers are willing to spend more. Therefore, it is imperative for every restaurant to retain loyal customers due to some positive outcome.

Research found that various determinants affect customer loyalty such as service quality, price fairness, food quality, environment, location, customer trust, perceived value, customer satisfaction, and image (Moorthy et al., 2017; Haghighi et al., 2012; Jin, Lee \& Huffman, 2012; Ryu et al., 2012; Ha \& Jang, 2010; Ryu et al., 2008; Kwun \& Oh, 2004; Kandampully \& Suhartanto, 2000; Mattila, 2001a; Qu, 1997). However, there has been little focus on hotel restaurant in the food and beverage context. In this study, three variables that are service quality, food quality and image were chosen as factors affecting customer loyalty. Apparently, restaurant which fails to deliver good quality of service, food and image might consequently be unsuccessful to build customer loyalty. In restaurant industry, researchers affirmed that good food and service had contributed to customer loyalty (Ma et al., 2014; Olsen, 2002; Baker \& Crompton, 2000). Thus, the proposition suggests that service quality, food quality and image are crucial in measuring customer loyalty in hotel restaurant context.

\section{REVIEW OF LITERATURE Customer Loyalty}

Attaining customer loyalty should be an essential component of an organization's long-term aim (Jin, Line \& Goh, 2013; Srivastava \& Rai, 2013). Importantly, loyal customers have higher commitment and stronger emotional bonds with the particular company (Gounaris \& Stathakopoulos, 2004). Yoo and Bai (2013) affirm that loyal customers tend to become less susceptible with competitor's marketing strategies.

Concept of customer loyalty is divided into two, namely behavioral and attitudinal. According to Alan and Kunal (1994), behavioral concept measures repeat patronage frequency and attitudinal concept refers to psychological commitment with the brand or business. In hospitality industry, the latter concept has been employed to measure customer loyalty (Han \& Ryu, 2009; Schall, 2003; Mattila, 2001b). A customer who has intention to repurchase and recommend to others has higher chance to remain with the restaurant (Kandampully \& Suhartanto, 2000). Thus, in this study, attitudinal approach is used to assess customer loyalty of hotel restaurant.

\section{Service Quality}

Service quality is an important factor in customer's restaurant selection (Soriano, 2002) and is regarded as an important strategy in in restaurant positioning (Chow, Lau, Lo, Sha \& Yun, 2007). Importantly, restaurant customers desire unique and memorable service experiences (Walls, 
Okumus, Wang \& Kwun, 2011) and might serve as a point of competitive advantage in the increasingly competitive restaurant industry. SERVQUAL is often used as a scale to measure the concept of service quality (Parasuraman, Zeithaml \& Berry, 1988). However, in this study, a generic service quality instrument is used as proposed by Dogdubay and Avcikurt (2008).

Superior service quality has the aptitude to improve customer loyalty (Manhas \& Tukamushaba, 2015). Evidently, empirical studies in restaurant setting demonstrate that improving service quality positively influences customer loyalty (Carranza, Díaz, \& Martín-Consuegra, 2018; Mhlanga, 2018; Hyun, 2010). It highlights the importance of service quality in determining customer loyalty in restaurant context. Given these, the following hypothesis is developed:

\section{H1: Service quality has significant relationship on customer loyalty}

\section{Food Quality}

Customers evaluate food quality from various attributes including taste, temperature, portion size (Qu, 1997), menu variety and nutritional value (Kivela, Inbakaran \& Reece, 1999). In the restaurant context, generally, Lewis (1981) further discussed that food quality has found to be the most important factor for customers in selecting restaurants. This is especially true due to the central product of any restaurant is food. Supporting the findings, previous researchers agreed that food quality is one of many factors that are identified as an important factor for restaurants (Qu, 1998; Ha \& Jang, 2010; Ma, Qu \& Njite, 2011). Ma et al. (2010) claimed that food quality can outweigh other determinants such as environment and service attributes, emphasizing the importance of food quality.

Apparently, food quality is a key determinant in building customer loyalty through satisfaction (Clark \& Wood, 1999) especially in restaurant. Similarly, previous researchers (Ha \& Jang, 2010; Namkung \& Jang, 2007; Sulek \& Hensley, 2004) agreed that food quality is an important component for customer loyalty. Ha and Jang (2010) found that food quality has a positive relationship with customer loyalty. Hence, identifying the key element such as food quality in determining customer loyalty is deemed crucial. Thus, the following hypothesis was formulated:

\section{H2: Food quality has significant relationship on customer loyalty}

\section{Image}

Image is considered as important factor to enhance marketing activities. Accordingly, image can influence customer's mind through various effects such as advertising, word-of-mouth, public relations, physical image and actual experiences (Normann, 1991). According to Kandampully and Suhartanto (2000), image has influence in customer's buying decision. As hotel restaurants carry the reputation of the hotel image, Nguyen (2006) asserts that many hotel operators improving physical environment that creates perceivable and positive images for customers. Thus, the importance has made image as an important variable to influence customer's perception. 
Previous study found that image can directly influence customer loyalty (Ma et al., 2014). Generally, researchers found that image improves customer loyalty in airline (Ostrowsky, O’Brien \& Gordon, 1993), hotel (Liat, Mansori \& Huei, 2014; Kandampully \& Hu, 2007; Kandampully \& Suhartanto, 2000), telecommunication (Lai, Griffin \& Babin, 2009), banking (Bloemer, De Ruyter \& Peeters, 1998) and retail industries (Clottey, Collier \& Stodnick, 2008). Similarly, a study conducted on coffee shop in Taiwan revealed that brand image significantly influence customer loyalty (Tu, Wang \& Chang, 2012). Consequently, a research hypothesis is developed:

\section{H3: Image has significant relationship on customer loyalty}

By determining the relationship between service quality, food quality and image, restauranteurs would better know how to improve their service and food quality as well as to build an attractive image. These would enhance their marketing efforts to optimize the effective use of their resources. This study, therefore, proposed a model which investigated the relationship between abovementioned factors to predict customer loyalty in a hotel restaurant context.

\section{METHODS}

\section{Research Design}

This quantitative study adopted cross-sectional design, where the data was collected at one point of time. The design was employed to obtain information to measure the relationship between independent variables (service quality, food quality and image) and dependent variable (customer loyalty). Figure 1 illustrates the conceptual framework of the study.

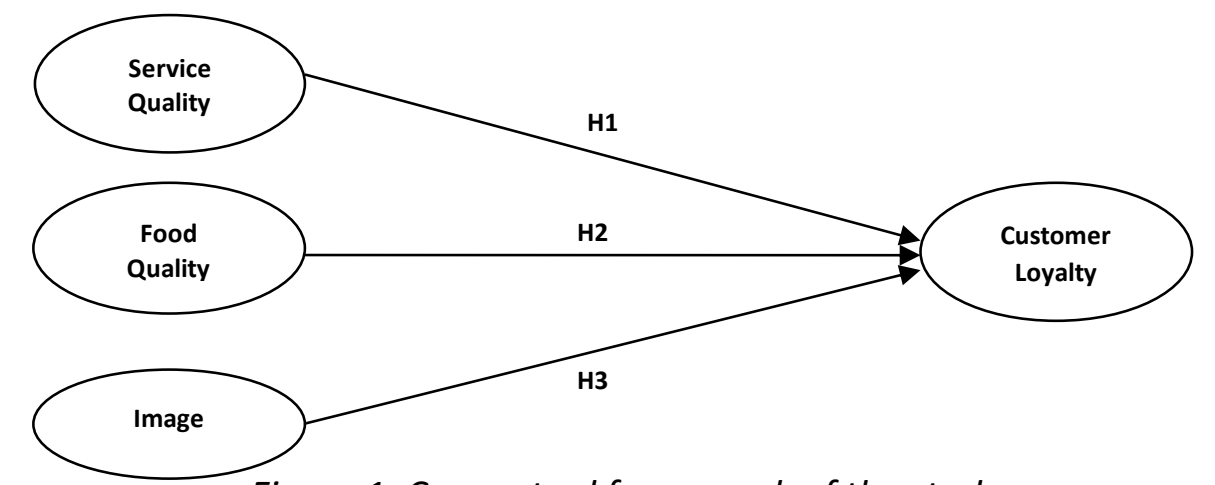

Figure 1: Conceptual framework of the study

\section{Questionnaire Development}

A 17-item instrument was assembled based on previous studies and comprised into three main sections. Section A, B, C and D collected information on customer's perception of different aspects of their dining experience. Food quality (Section A) and service quality (Section B) was measured using four items respectively, in which adapted from Dogdubay and Avcikurt (2008). Respectively, examples of food quality and service quality items are, "Food served at XXX restaurant is visually appealing" and "Waiter displays a thorough knowledge about the menu". Section C represents items of image that consisted of 3 items. Example of item was, "Décor of the restaurant is attractive". In 
Section D, customer loyalty was measured using six items adapted from Ryu et al. (2012), and Dogdubay and Avcikurt (2008). Example of the item is, "Given other choices, I would still return to this restaurant". The questionnaire was designed using five-point Likert scale ( $1=$ strongly disagree to 5 = strongly agree). Besides, Section E collected customer's demographic information, such as gender, age, occupation, purpose of visit, number of visits and etc.

\section{Data Collection}

The target population of this study was the customers who visited a restaurant located at 2-star hotel in Terengganu, Malaysia. The hotel where the study is conducted also considered as training hotel for university students. Thus, it is presumed that most of the respondents were predominantly students. Using convenient sampling technique, the restaurant agreed to participate in the study and permission to administer the questionnaire was granted. During 4-week time period, customers who visited the hotel restaurant during lunch and dinner were politely requested to fill in the questionnaires. The respondents completed the questionnaires in the presence of the researchers and completed questionnaires were collected immediately. A total of 268 questionnaires were distributed. After removing invalid responses, a total of 231 usable responses were used for further data analysis, indicating $86.2 \%$ of valid response rate.

\section{Statistical Analyses}

The researchers analyzed the data using SPSS 23. Descriptive statistics was used to describe the demographic information of the respondents. The model and the hypotheses were simultaneously tested using multiple regression. Internal consistency of the items of each construct was examined prior to multiple regression to ensure its reliability.

\section{ANALYSIS AND RESULTS \\ Demographic Profiling}

The samples of this study 231 customers that were dined at the particular hotel restaurant. Table 1 presents the demographic characteristics of the sample. 
INTERNATIONAL JOURNAL OF ACADEMIC RESEARCH IN BUSINESS AND SOCIAL SCIENCES Vol. 8, No. 10, Oct. 2018, E-ISSN: 222 2-6990 @ 2018 HRMARS

Table 1: Demographic characteristics of the sample.

\begin{tabular}{llcc}
\hline Variable & \multicolumn{1}{c}{ Categories } & Frequency & Percent \\
\hline Age & $18-24$ & 124 & 53.7 \\
& 25 to 34 & 67 & 29.0 \\
& 35 to 44 & 25 & 10.8 \\
& 45 to 54 & 13 & 5.6 \\
& $>55$ & 2 & .9 \\
\hline Marital & Single & 167 & 72.3 \\
status & Married & 64 & 27.7 \\
\hline Occupation & Student & 147 & 63.6 \\
& Administrative/ Clerk & 26 & 11.3 \\
& Professional & 30 & 13.0 \\
& Businessman & 24 & 10.4 \\
& Retiree & 3 & 1.3 \\
& Unemployed & 1 & .4 \\
\hline Monthly & inM1000 & 74 & 32.0 \\
& RM1001 - RM2500 & 52 & 22.5 \\
& RM2501 - RM4000 & 39 & 16.9 \\
& $>$ RM4001 & 29 & 12.6 \\
& Not applicable & 37 & 16.0 \\
\hline Educational & Diploma/ Certificate & 74 & 32.0 \\
& Bachelor's Degree & 114 & 49.4 \\
& Master's Degree & 38 & 16.4 \\
& Doctorate Degree & 5 & 2.2 \\
\hline
\end{tabular}

Gender of the sample was evenly distributed, representing $52.8 \%$ of male and 47.2 of female. The dominant age group of the respondents was $18-24$ years (53.7\%), followed by $25-34$ years (29.0\%), $35-44$ years $(10.8 \%), 45-54$ years $(5.6 \%)$ and 54 years and older (.9\%). Students accounted for more than $60 \%$ of the respondents (63.6\%). The other occupation group of respondents on the professional representing $13.0 \%$, white collar level was administration/ clerical represented $11.3 \%$ and businessman accounting for $10.4 \%$ of the respondents. Retirees and unemployed groups represented only a small portion of the respondents.

In term of monthly income, 74 respondents (32.0\%) earned less than MYR1000 and followed by 52 respondents (22.5\%) earned between MYR1001 and MYR2500. More than 15\% (16.9\%) of the respondents earned between MYR2501 and MYR4000 while 29 respondents (12.6\%) earned MYR4001 and above. 37 respondents recorded their monthly income as not applicable. It was assumed that respondents who were students, retirees and unemployed contributed to this figure. In regard to educational level, almost half of the respondents (49.4\%) have bachelor's degree and 74 respondents (32.0\%) have diploma/ certificate. In addition, 38 respondents (16.4\%) have master's degree while only 5 respondents (2.2\%) have doctoral degree. 
Internal reliability of the 17 -items scale was examined by using reliability statistics. The result of alpha values was between .661 and .832. Table 2 displays the reliability coefficient of each construct of the study. Summarizing from the table, the alpha values range was between moderate and very good (Hair, Money, Samouel and Page, 2007). Generally, the alpha values for the internal consistency of all study variables were considered as acceptable, as the alphas were all above .60. It was consistent with Hinton, McMurray and Brownlow, Cozens (2004), in which they affirmed that an alpha value score in the range of .50 to .70 is commonly accepted and considered to be the criterion for demonstrating the internal consistency of a reliable scale. Multiple scale items were then summated to create a summated scale for each construct for further analysis.

Table 2: Reliability coefficient

\begin{tabular}{lcc}
\hline \multicolumn{1}{c}{ Variables } & Alpha value & Items \\
\hline Food quality & .832 & 4 \\
Service quality & .763 & 4 \\
Image & .661 & 3 \\
Customer loyalty & .794 & 6 \\
\hline
\end{tabular}

\section{Results of Multiple Regression Analysis}

Multiple linear regression was performed to test the relationship among variables in the study with significant level of 0.05 . Various aspects were tested as part of the multiple regression procedure. The normal probability plot in Figure 2 shows that the residuals are normally distributed. There was a random pattern in scatter plot, indicated that the residuals have constant variance, independent on each other and linearly related. Figure 3 shows only three outliers (exceed -3.3) exists, however, it satisfied the assumption of zero mean. In addition, all tolerance values are more than 0.10 and VIF values of less than 10, indicated no violation of multicollinearity. Hence, all multiple regression assumptions are satisfied.

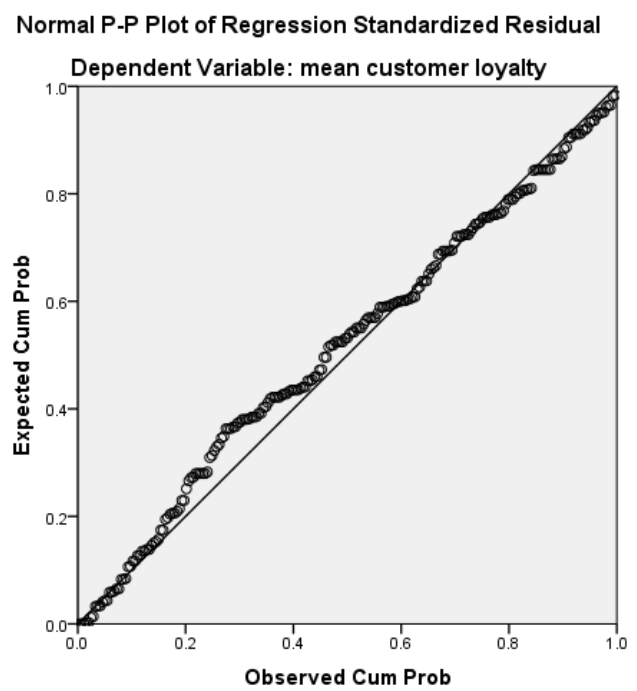

Figure 2: Normal probability plot 


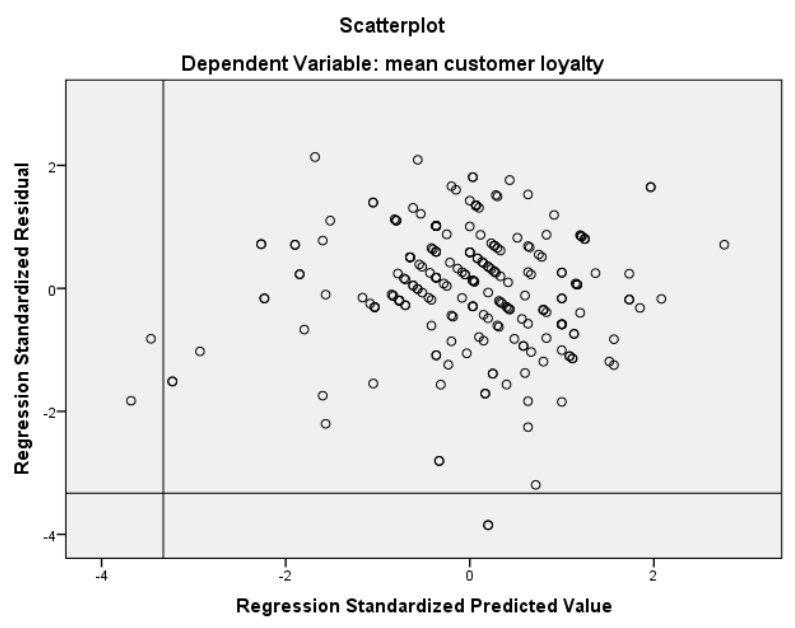

Figure 3: Scatter plot

This model made a statistically significant contribution towards customer loyalty and it explained $58 \%$ of the variations in customer loyalty ratings. The remaining $42 \%$ is explained by other predictor variables. The model as a whole was significant $[F(3,227)=105.2, p<.001]$. All the three predictors namely food quality, service quality and image had significant contribution on customer loyalty $(p<.001)$. Among the three predictors, in terms of importance, service quality made the largest unique contribution, recording a higher beta value $(\beta=.426)$. It is followed by image, and food quality with the beta values of $\beta=.251$ and $\beta=.234$ respectively. The following table reports the summary of multiple regression analysis.

Table 3: Model summary of multiple regression analysis

\begin{tabular}{llll}
\hline & B & SE B & $\boldsymbol{\beta}$ \\
\hline Constant & .619 & .166 & \\
Service Quality & .372 & .049 & $.426^{*}$ \\
Food Quality & .216 & .047 & $.234^{*}$ \\
Image & .232 & .054 & $.251^{*}$ \\
\hline
\end{tabular}

Note: $R^{2}=.58,{ }^{*} p<.001$

\section{DISCUSSIONS AND IMPLICATIONS}

The main objective of this study is to determine the relationship between service quality, food quality and image towards customer loyalty at 2-star hotel restaurant in Terengganu, Malaysia. The current study extends the understanding of factors affecting customer loyalty in restaurant context. The results showed that all three independent variables have significant relationship with customer loyalty. As a result, all hypotheses of the study were accepted. This study provides strong evidence to support the notion that service quality, food quality and image influenced customer loyalty (Carranza, Díaz, \& Martín-Consuegra, 2018; Mhlanga, 2018; Ma et al., 2014; Ha \& Jang, 2010; Hyun, 2010; Namkung \& Jang, 2007; Sulek \& Hensley, 2004). 
The findings suggested that service quality, food quality and image are important predictors of customer loyalty that has important managerial implications. Considering these vital determinants should result in high restaurant food and service quality, in which would enhance customer loyalty at the hotel restaurant. More specifically, the findings suggest that service quality is the most important factor and is likely to increase customer loyalty. This aspect of service quality is seen to be more important in the minds of hotel restaurant's customers. Failure to provide favorable service quality is unlikely to improve customer loyalty. Thus, restauranteurs should therefore adjust and improve their service quality that meet customer's expectation and further strengthen their loyalty to the restaurant, which in turn enhances customer repeat patronage.

\section{LIMITATIONS AND FUTURE RESEARCH}

It is believed that the findings and insights provided by this study might be more applicable to hotel restaurants, thus, certain limitations might provide opportunities for future research. This study provides evidence on important factors of customer loyalty in only one type of dining restaurant. Thus, it is possible that the findings might differ in other types of restaurant, for example in quick service restaurant that has different type of food and service provided. When related to socially embedded phenomena, research demonstrates that expectations of customer vary across restaurant categories (Line, Runyan, Costen, Frash, \& Antun, 2012). Therefore, it might be meaningful to extent the variables of the study beyond hotel restaurant setting to investigate whether the same dimensions remain intact.

Another limitation was that, the respondents of the study were predominantly students. Thus, the data might not provide holistic assessment within the model. Future research might provide restauranteurs with additional insights by including more customers with higher level of income. Thus, extension to this work might provide better assumption as customers with higher income are more likely to have higher level of expectation.

\section{Corresponding Author}

Mohd Aliff Abdul Majid*

Department of Food Service and Management,

Faculty of Food Science and Technology,

Universiti Putra Malaysia, 43400 UPM Serdang, Selangor, Malaysia

Email: mh.aliff@gmail.com

\section{REFERENCES}

Baker, D. A., \& Crompton, J. L. (2000). Quality, satisfaction, and behavioral intention. Annals of Tourism Research, 27(3), 785-804.

Bloemer, J., De Ruyter, K., \& Peeters, P. (1998). Investigating drivers of bank loyalty: the complex relationship between image, service quality and satisfaction. International Journal of Bank Marketing, 16(7), 276-286. 
INTERNATIONAL JOURNAL OF ACADEMIC RESEARCH IN BUSINESS AND SOCIAL SCIENCES

Vol. 8, No. 10, Oct. 2018, E-ISSN: 222 2-6990 @ 2018 HRMARS

Carranza, R., Díaz, E., \& Martín-Consuegra, D. (2018). The influence of quality on satisfaction and customer loyalty with an importance-performance map analysis: Exploring the mediating role of trust. Journal of Hospitality and Tourism Technology.

Chow, I. H., Lau, V. P., Lo, T. W., Sha, Z., \& Yun, H. (2007). Service quality in restaurant operations in China: Decision- and experiential-oriented perspectives. International Journal of Hospitality Management, 26(3), 698-710.

Clark, M. A., \& Wood, R. C. (1999). Consumer loyalty in the restaurant industry: A preliminary exploration of the issues. British Food Journal, 101(4), 317-327.

Clottey, T. A., Collier, D. A., \& Stodnick, M. (2008). Drivers of customer loyalty in retail store environment. Journal of Service Science, 1(1), 35-47.

Department of Statistics Malaysia. (2016). Economic census 2016 - Food and beverage services. Available

https://www.dosm.gov.my/v1/index.php?r=column/cthemeByCat\&cat=415\&bul_id=bUJEdEIV OTViR2g3VzZzamFTa1pTZz09\&menu id=b0pIV1E3RW40VWRTUkZocEhyZ1pLUT09

Dogdubay, M., \& Avcikurt, C. (2008). Customer loyalty in the specialty restaurants: An example from Istanbul. Available at https://emnet.univie.ac.at/uploads/media/Dogdubay AVCIKURT 01.pdf

Eakuru, N., \& Mat, N. K. N. (2008). The application of structural equation modeling (SEM) in determining the antecedents of customer loyalty in banks in South Thailand. The Business Review, 10(2), 129-139.

Gounaris, S., \& Stathakopoulos, V. (2004). Antecedents and consequences of brand loyalty: An empirical study. Journal of Brand Management, 11(4), 283-306.

Ha, J., \& Jang, S. (2010). Effects of service quality and food quality: The moderating role of atmospherics in an ethnic restaurant segment. International Journal of Hospitality Management, 29, 520-529.

Haghighi, M., Dorosti, A., Rahnama, A., \& Hoseinpour, A. (2012). Evaluation of factors affecting customer loyalty in the restaurant industry. African Journal of Business Management, 6(14), 5039-5046.

Hair, J. F. H., Money, A. H., Samouel, P., \& Page, M. (2007). Research methods for business. West Sussex: John Wiley \& Sons Ltd.

Han, H., \& Ryu, K. (2009). The roles of the physical environment, price perception, and customer satisfaction in determining customer loyalty in the restaurant industry. Journal of Hospitality \& Tourism Research, 33(4), 487-510.

Hinton, P. R., McMurray, I., Brownlow, C., \& Cozens, B. (2004). SPSS explained. New York: Routledge. Hyun, S. S. (2010). Predictors of relationship quality and loyalty in the chain restaurant industry. Cornell Hotel and Restaurant Administration Quarterly, 51(2), 251-267.

Ismail, T. A. T., Zahari, M. S. M., Shariff, F. M., \& Suhaimi, M. Z. (2016). Hotel restaurant brand attributes, dining experience, satisfaction and behavioral intention: Developing a study framework. In S. M. Radzi, M. H. M. Hanafiah, N. Sumarjan, Z. Mohi, D. Sukyadi, K. Suryadi, \& P. Purnawarman (eds.), Heritage, culture and society: Research agenda and best practices in the hospitality and tourism industry, (pp. 185-190). London: CRC Press. 
INTERNATIONAL JOURNAL OF ACADEMIC RESEARCH IN BUSINESS AND SOCIAL SCIENCES

Vol. 8, No. 10, Oct. 2018, E-ISSN: 222 2-6990 @ 2018 HRMARS

Jin, N. P., Lee, S., \& Huffman, L. (2012). Impact of restaurant experience on brand image and customer loyalty: moderating role of dining motivation. Journal of Travel \& Tourism Marketing, 29(6), 532551.

Jin, N., Line, N. D., \& Goh, B. (2013). Experiential value, relationship quality, and customer loyalty in full-service restaurants: The moderating role of gender. Journal of Hospitality Marketing \& Management, 22, 629-700.

Liat, C. B., Mansori, S., \& Huei, C. T. (2014). The associations between service quality, corporate image, customer satisfaction, and loyalty: Evidence from the Malaysian hotel industry. Journal of Hospitality Marketing \& Management, 23(3), 314-326.

Line, N., Runyan, R. C., Costen, W., Frash, R., \& Antun, J. M. (2012). Where everybody knows your name: Homophily in restaurant atmospherics. Journal of Hospitality Marketing \& Management, 21(1), 1-19.

Kandampully, J., \& Hu, H. H. (2007). Do hoteliers need to manage image to retain loyal customers?. International Journal of Contemporary Hospitality Management, 19(6), 435-443.

Kandampully, J., \& Suhartanto, D. (2000). Customer loyalty in the hotel industry: The role of customer satisfaction and image. International Journal of Contemporary Hospitality Management, 12(6), 346-351.

Kivela, J., Inbakaran, R., \& Reece, J. (1999). Consumer research in the restaurant environment, Part 1: A conceptual model of dining satisfaction and return patronage. International Journal of Contemporary Hospitality Management, 11(5), 205-222.

Kwun, J. W., \& Oh, H. (2004). Effects of brand, price, and risk on customers' value perceptions and behavioral intentions in the restaurant industry. Journal of Hospitality and Leisure Marketing, 11 (1), 31-49.

Lai, F., Griffin, M., \& Babin, B. J. (2009). How quality, value, image, and satisfaction create loyalty at a Chinese telecom. Journal of business research, 62(10), 980-986.

Lewis, R. C. (1981). Restaurant advertising-appeals and consumers intentions. Journal of Advertising Research, 21(5), 69-74.

Ma, E., Qu, H., \& Eliwa, R. A. (2014). Customer loyalty with fine dining: The moderating role of gender. Journal of Hospitality Marketing \& Management, 23(5), 513-535.

Ma, E., Qu, H., \& Njite, D. (2011). U.S. customer perceptions toward Chinese restaurant service quality: An importance-performance approach. Journal of Foodservice Business Research, 14(3), 290-308.

Majid, M. A. A., Alias, M. A. M., Samsudin, A., \& Chik, C. T. (2016). Assessing customer-based brand equity ratings in family restaurant. Procedia Economics and Finance, 37, 183-189.

Manhas, P. S., \& Tukamushaba, E. K. (2015). Understanding service experience and its impact on brand image in hospitality sector. International Journal of Hospitality Management, 45, 77-87.

Mattila, A. S. (2001a). The effectiveness of service recovery in a multi-industry setting. Journal of Services Marketing, 15(7), 583-596.

Mattila, A. S. (2001b). Emotional bonding and restaurant loyalty. Cornell Hotel and Restaurant Administration Quarterly, 42(6), 73-79. 
INTERNATIONAL JOURNAL OF ACADEMIC RESEARCH IN BUSINESS AND SOCIAL SCIENCES

Vol. 8, No. 10, Oct. 2018, E-ISSN: 222 2-6990 @ 2018 HRMARS

Mhlanga, O. (2018). Measuring restaurant service quality in East London, South Africa: A comparison of restaurant customer expectations and perceptions. African Journal of Hospitality, Tourism and Leisure, 7(2), 12.

Moorthy, K., Chee, L. E., Yi, O. C., Ying, O. S., Woen, O. Y., \& Wei, T. M. (2017). Customer loyalty to newly opened cafés and restaurants in Malaysia. Journal of Foodservice Business Research, 20(5), 525-541.

Namkung, Y., \& Jang, S. (2007). Does food quality really matter in restaurants? Its impact on customer satisfaction and behavioral intentions. Journal of Hospitality \& Tourism Research, 31(3), 387409.

Nguyen, N. (2006). The collective impact of service workers and servicescape on the corporate image formation. International Journal of Hospitality Management, 25, 227-244.

Normann, R. (1991). Service management: Strategy and leadership in service business. Wiley.

Olsen, S. O. (2002). Comparative evaluation and the relationship between quality, satisfaction, and repurchase loyalty. Journal of the Academy of Marketing Science, 30(3), 240-249.

Ostrowski, P. L., O'Brien, T. V., \& Gordon, G. L. (1993). Service quality and customer loyalty in the commercial airline industry. Journal of Travel Research, 32(2), 16-24.

Parasuraman, A., Zeithaml, V. A., \& Berry, L. L. (1988). Servqual: A multiple-item scale for measuring consumer perceptions of service quality. Journal of Retailing, 64(1), 12.

Polyorat, K., \& Sophonsiri, S. (2010). The influence of service quality dimensions on customer satisfaction and customer loyalty in the chain restaurant context: A Thai case. Journal of Global Business and Technology, 6(2), 64-76.

Qu, H. (1997). Determinant factors and choice intention for Chinese restaurant dining. Journal of Restaurant \& Food Service Marketing, 2(2), 35-49.

Ryu, K., Lee, H. R., \& Kim, W. G. (2012). The influence of the quality of the physical environment, food and service on restaurant image, customer perceived value, customer satisfaction, and behavior intentions. International Journal of Contemporary Hospitality Management, 24(2), 200-223.

Ryu, K., Han, H., \& Kim, T. H. (2008). The relationships among overall quick-casual restaurant image, perceived value, customer satisfaction, and behavioral intentions. International Journal of Hospitality Management, 27(3), 459-469.

Salleh, S., Hashima, N. H., \& Murphy, J. (2015). Instagram marketing: a content analysis of top Malaysian restaurant brands. E-Review of Tourism Research, 6, 1-5.

Schall, M. (2003). Best practices in the assessment of hotel-guest attitudes. Cornell Hotel and Restaurant Administration Quarterly, 44(2), 51-65.

Shamsudin, M. N., \& Selamat, J. (2005). Changing retail food sector in Malaysia. PECC Pacific Food System Outlook, 6, 11-13.

Shoemaker, S., \& Lewis, R. C. (1999). Customer loyalty: The future of hospitality marketing. International Journal of Hospitality Management, 18(4), 345-370.

Soriano, D. (2002). Customers' expectations factors in restaurants: The situation in Spain. International Journal of Quality \& Reliability Management, 19(8/9), 1055-1067.

Srivastava, M., \& Rai, A. K. (2013). Investigating the mediating effect of customer satisfaction in the service quality-customer loyalty relationship. Journal of Consumer Satisfaction, Dissatisfaction \& Complaining Behavior, 26, 95-109. 
Sulek, J. M., \& Hensley, R. L. (2004). The relative importance of food, atmosphere, and fairness of wait: the case of a full-service restaurant. Cornell Hospitality Quarterly, 45(3), 235-247.

Tu, Y. T., Wang, C. M., \& Chang, H. C. (2012). Corporate brand image and customer satisfaction on loyalty: An empirical study of Starbucks coffee in Taiwan. Journal of Social and Development Sciences, 3(1), 24-32.

Wijaya, S., Widjaja, D. C., \& Hariyanto, A. (2016). The underlying factors affectig consumers' behavioral intentions in foodservice business in Surabaya, Indonesia. In S. M. Radzi, M. H. M. Hanafiah, N. Sumarjan, Z. Mohi, D. Sukyadi, K. Suryadi, \& P. Purnawarman (eds.), Heritage, culture and society: Research agenda and best practices in the hospitality and tourism industry, (pp. 53-57). London: CRC Press.

Wills, B. (2009). The business case for environmental sustainability (green): Achieving rapid returns from the practical integration of Lean \& Green. Available at http://www.leanandgreensummit.com/LGBC.pdf

Yoo, M., \& Bai, B. (2013). Customer loyalty marketing research: A comparative approach between hospitality and business journals. International Journal of Hospitality Management, 33, 166-177. 